\title{
Sanctuary and the Legal Topography of Pre-Reformation London
}

\author{
SHANNON MCSHEFFREY
}

In early sixteenth-century England, the presence of ecclesiastical sanctuaries in the legal, social, and religious landscape was a matter of great controversy. Any English church could offer temporary sanctuary to an accused felon, a privilege that expired after about forty days, following which the felon had to abjure the realm. ${ }^{1}$ More contentiously, by the late Middle Ages a number of English religious houses used their status as royallychartered liberties to offer sanctuary permanently, not only to accused criminals, but also to debtors, alien craftsmen, and, especially during the civil wars of the fifteenth century, political refugees. ${ }^{2}$ These ecclesiastical

1. See Krista Kesselring, "Abjuration and its Demise: The Changing Face of Royal Justice in the Tudor Period," Canadian Journal of History 34 (1999): 345-58; R. H. Helmholz, The ius commune in England: Four Studies (Oxford: Oxford University Press, 2001), 18-20.

2. On English law and sanctuary, see J. H. Baker, "The English Law of Sanctuary," Ecclesiastical Law Journal 2 (1990): 8-13; Helmholz, Ius commune, 16-81. On permanent sanctuary, see Isobel Thornley, "Sanctuary in Medieval London," Journal of the British Archaeological Association 38 (1932-33): 293-315; Thornley, "The Destruction of Sanctuary," in Tudor Studies, edited by R. W. Seton-Watson (London: Longmans, Green, and Company, 1924), 182-207; Thomas John de' Mazzinghi, Sanctuaries (Stafford: Halden \& Son, 1887), http://www.archive.org/download/sanctuaries00dema/sanctuaries00dema (accessed Dec. 2, 2008); Norman MacLaren Trenholme, The Right of Sanctuary in England: A Study in Institutional History (Columbia: University of Missouri, 1903), http://www.archive.org/download/ rightofsanctuary00trenrich/rightofsanctuary00trenrich (accessed Dec. 2, 2008); J. Charles Cox, The Sanctuaries and Sanctuary Seekers of Mediaeval England (London: G. Allen and Sons, 1911); E. W. Ives, "Crime, Sanctuary, and Royal Authority under Henry VIII: The

Shannon McSheffrey is a professor in the History Department at Concordia University in Montreal<mcsheff@alcor.concordia.ca>. Her thanks are due, for timely comments and encouragement, to Eric Reiter, Kit French, Ian Forrest, Karl Shoemaker, Michael Wasser, and the anonymous reviewers for $L H R$. 
liberties, small territories that exercised varying extents of juridical and political autonomy, considerably complicated the jurisdictional map of late medieval England. London in particular, with its host of liberties and peculiars, constituted a patchwork quilt of legal jurisdictions. Although the mayor and aldermen of London were wont to say that the "chyeff and most commodyous place of the Cytie of London" constituted "one hoole Countie and one hoole Jurisdiccion and libertie" over which its citizens ruled, saving only the authority of the king himself, ${ }^{3}$ this confident assertion of the City's jurisdiction over the metropolitan square mile was constantly belied by the presence of these liberties. The most notableand for the City, the most troubling - was the sanctuary at St. Martin Le Grand, a sizeable area within the bounds of the City, before 1503 governed by the dean and canons of the College of St. Martin, after 1503 absorbed into the lands attached to Westminster Abbey and ruled by the abbot. ${ }^{4}$ For about two centuries before St. Martin Le Grand was dissolved in 1542, its precinct was home to a thriving population of debtors, accused felons, and perhaps most numerously alien craftsmen, all seeking for various reasons

Exemplary Sufferings of the Savage Family," in On the Laws and Customs of England, edited by Morris S. Arnold et al. (Chapel Hill: University of North Carolina Press, 1981), 296-320; Peter Iver Kaufman, "Henry VII and Sanctuary," Church History 53 (December 1984): 465-76; Kaufman, The "Polytyque Churche": Religion and Early Tudor Political Culture, 1485-1516 (Macon, Georgia: Mercer University Press, 1986), 141-53; Gervase Rosser, "Sanctuary and Social Negotiation in Medieval England," in The Cloister and the World: Essays in Medieval History in Honour of Barbara Harvey, edited by John Blair and Brian Golding (Oxford: Clarendon Press, 1996), 57-79; Karl Blaine Shoemaker, "Sanctuary Law: Changing Conceptions of Wrongdoing and Punishment in Medieval European Law," (Ph.D. dissertation, University of California, Berkeley, 2001).

3. London, London Metropolitan Archives (Corporation of London Record Office) [LMA], Journals of the Court of Common Council, vol. 13, fol. 467r; Kew, The National Archives [TNA], STAC, 2/20/324, m. 5.

4. On St. Martin Le Grand, see Alfred John Kempe, Historical Notices of the Collegiate Church or Royal Free Chapel and Sanctuary of St. Martin-le-Grand, London (London: Longman, Hurst, Rees Orme, Brown, and Green, 1825), http://books.google.com/ books?id=mQ6f37KfHlAC (accessed Dec. 2, 2008); William Page, ed., "Colleges: St. Martin Le Grand," in A History of the County of London, edited by William Page (London: Constable, 1909) (hereafter VCH London), 555-66, http://www.british-history.ac.uk/report .aspx?compid=35385 (accessed Dec. 2, 2008); Thornley, "Sanctuary"; Thornley, "Destruction of Sanctuary"; Marjorie B. Honeybourne, "The Sanctuary Boundaries and Environs of Westminster Abbey and the College of St. Martin-le-Grand," Journal of the British Archaeological Association 38 (1932-33): 316-34; Caroline M. Barron, London in the Later Middle Ages: Government and People 1200-1500 (Oxford: Oxford University Press, 2004), 36-37. Honeybourne uses the abbot's statement in the 1530s dispute to outline the boundaries of St. Martin's sanctuary, but apparently did not see the other documents discussed here, which outline the contentious nature of the abbot's claim. 
to avoid civic or royal jurisdiction. ${ }^{5}$ The dissolution of religious houses which accompanied the English Reformation greatly lessened, although did not altogether eradicate, the privileges of St. Martin's.

Underpinning the practice of sanctuary in late medieval London was a complicated amalgam of Christian ideology and political gamesmanship. In a legal sense, the theory and practice of sanctuary straddled a number of legal regimes-the canon law of the Church; the law of the royal courts both criminal and civil; and local customary jurisdictions of manor, town, or city. ${ }^{6}$ As Richard Helmholz has delineated, the English practice of sanctuary, as granted by royal charter and upheld by royal courts and by statute, had an uneasy and imprecise relationship with the medieval church's legal definitions of sanctuary and asylum. Much of the prior scholarship on English sanctuary assumed that disputes about sanctuary were another episode in battles between an overpowerful medieval church and a modernizing and finally triumphant state. Helmholz, by contrast, demonstrates that the scope of medieval English sanctuary, as accepted by the royal courts and government, was actually rather wider than that allowed by official church law. ${ }^{7}$ The English practice of temporary sanctuary, for instance, where an accused criminal who sought sanctuary in a church had to leave the church and abjure the realm within forty days, did not derive from canon law and was in some ways inconsistent with it. Such inconsistencies were not, however, at the root of late medieval conflicts over sanctuary; English canonists, recognizing the extent to which sanctuary privileges bridged the canon law/ common law frontier, did not object to these "customs of England," as they termed them. ${ }^{8}$ Similarly, the late medieval English practice whereby debtors and alien craftsmen took advantage of the idea of a church's immunity from secular jurisdictions in order to escape their creditors and guild supervision was a stretch of the original spirit of the church's immunity claims. Ecclesiastical immunity was meant to protect the church and its members from violence rather than to allow escape from legal processes for debt or

5. Most of the residents of the precinct testifying in the 1536-37 Star Chamber dispute about St. Martin Le Grand, discussed below, were aliens (TNA, STAC 2/23/266), although one of those aliens may first have sought refuge in St. Martin's as an accused felon: John Richardson, alien shoemaker and witness in 1536 (ibid., m. 13), had in 1521, already apparently resident in St. Martin's, been pardoned for murder (J. S. Brewer et al., eds., Letters and Papers, Foreign and Domestic, of the Reign of Henry VIII, 21 vols. and addenda [London: Public Record Office, 1862-1932], 3/1:553, no. 1379/20), http://www.british-history.ac.uk/ report.aspx ?compid=91066 (accessed Dec. 2, 2008). See also Gervase Rosser's description of the Westminster sanctuary precinct: Medieval Westminster 1200-1540 (Oxford: Clarendon Press, 1989), 155-56.

6. See especially Helmholz, Four Studies; and Baker, "English Law."

7. Helmholz, Ius commune, 58-81.

8. Helmholz, Ius commune, 18, 60-61. 
economic regulation. ${ }^{9}$ Late medieval English conceptualization of sanctuary effectively combined the English concept of the liberty-a territory, ecclesiastical or secular, exempt from other jurisdictions (privileges that St. Martin's had long had, perhaps since the Anglo-Saxon era)—with the holy space of the church protected by ecclesiastical immunity. ${ }^{10}$ The interpenetration of these ideas, tying the jurisdictional exemptions of the liberty to the church ground's sacrality, underlay the extension in the fourteenth century of sanctuary's jurisdictional exemptions not only to crime but to debt litigation and guild regulation.

The practice of sanctuary in late medieval England alerts us not only to consider how late medieval common law and canon law interlaced, but also how thoroughly imbricated were late medieval and early modern conceptions of kingship, justice, mercy, and Christian religion. The claim of sanctuary seekers to asylum at St. Martin Le Grand was made in reference to the sanctuary's attachment not only to the privileges of a particular religious house but also to the idea of holiness embodied in the church's building and the lands over which it ruled. That idea of holiness in turn was intricately interwoven with St. Martin's status as a royally chartered liberty, an area designated by the crown as independent from all authorities, even the crown itself. At the same time as the liberty conferred independence from civic, diocesan, and royal officials, and immunity from the ordinary processes of law, those rights were granted by, and strongly connected to, the Christian king and his protection. Royal protection of sanctuaries had its prosaic, strategic aspect: St. Martin's sanctuary thrived not only because of the sacrilege that would have been attendant on its breach but because its presence in the midst of London served a useful purpose to the Crown in reining in the overweening ambitions of the City. At the same time, however, the king's sponsorship and patronage of the royal sanctuaries were powerful demonstrations of his royal and Christian mercy, which was at the heart of late medieval and Tudor royal authority, as Krista Kesselring and others have argued. ${ }^{11}$

9. Helmholz, Ius commune, 70-72, regarding sanctuary for debt (Helmholz does not mention the use of sanctuary precincts by alien craftsmen, who made up perhaps the largest proportion of the population in both St. Martin Le Grand and in Westminster). Helmholz notes that a fifteenth-century defense of Westminster's sanctuary privilege ingeniously argued that debtors, if punished by imprisonment, could be "tormented in their bodies" through being jailed, and thus that sanctuary was appropriate for debtors as well as criminals. Ibid., 71. See also James R. Hertzler, "The Abuse and Outlawing of Sanctuary for Debt in SeventeenthCentury England," The Historical Journal 14 (1971): 467-77.

10. "Colleges: St Martin le Grand," in VCH London, 555-66; Thornley, "Sanctuary," 299, 301; Shoemaker, "Sanctuary Law," 215-16, 230-32. On other ecclesiastical peculiars, see R. N. Swanson, "Peculiar Practices: The Jurisdictional Jigsaw of the Pre-Reformation Church," Midland History 26 (2001): 69-95.

11. On the importance of mercy to contemporary kingship, see Krista Kesselring, Mercy 
While sanctuary had an important place in the conceptualization and administration of justice, of relations between the church and the crown, and of the ties between law, political power, and Christian religion, specific sanctuaries, such as the liberty of St. Martin Le Grand, were more than concepts: they were physically present in the English landscape and part of quotidian life in the kingdom. Relatively little has been written about how permanent sanctuaries functioned in late medieval England's legal topography. They were territories marked apart-as its fifteenth-century dean, Richard Caudray, put it, St. Martin Le Grand was located in a space both "in and yet not of the City." ${ }^{2}$ St. Martin's privileges were more extensive than the other liberties in late medieval London, but it was by no means alone as a peculiar jurisdiction within the City limits or in its immediate outskirts. The monasteries, nunneries, and hospitals that dotted the City, some with relatively extensive precincts with tenements leased to lay residents, had varying jurisdictional immunities, especially as concerned guild regulation - and thus often, like St. Martin's, had considerable populations of alien artisans and debtors. Similarly, some nonecclesiastical territories were outside the City jurisdictionally, if within it geographically: such was the case with the manor of Blanchappleton, a privately-held manor in (but not of) Aldgate ward until the City was able to bring it under its jurisdiction in the 1470s, and two of the law inns within the City boundaries, Barnard's Inn and Thavie's Inn. All of these privileged areas disrupted the City's authority simply by their presence, and some were seen as havens of wrongdoers fleeing City jurisdiction. The precincts of the hospitals of St. Katharine by the Tower and of St. Mary Spital, both on the eastern

and Authority in the Tudor State (Cambridge: Cambridge University Press, 2003); Pat McCune, "Justice, Mercy, and Late Medieval Governance," Michigan Law Review 89 (1991): 1671-77; Edward Powell, Kingship, Law, and Society: Criminal Justice in the Reign of Henry V (Oxford: Clarendon Press, 1989), 229-32.

12. Registrum Collegii Sancti Martini Magni, London, Westminster Abbey Muniments [WAM], Book 5, fol. 57v; Henry VI repeated this locution in a writ transcribed by (or recorded at the command of) Richard Caudray, ibid., fol. 70r, and it appears to have entered into a 1475 judgment in the court of Common Pleas as an illustration of the difference between the prepositions "in" and "of"; David J. Seipp, An Index and Paraphrase of Printed Year Book Reports, 1268 - 1535, 2008, http://www.bu.edu/law/seipp/index.html, Seipp 1475.052 (YB Mich 15 Edw. 4 pl. 20).

I have found a number of works useful for thinking through the significance of the sanctuary space of St. Martin Le Grand: Henri Lefebvre, The Production of Space (Oxford: Blackwell, 1991); Michel de Certeau, The Practice of Everyday Life, trans. Steven Rendall (Berkeley: University of California Press, 1984), 91-110; Henrietta L. Moore, Space, Text, and Gender: An Anthropological Study of the Marakwet of Kenya (Cambridge: Cambridge University Press, 1986); Susan Signe Morrison, Women Pilgrims in Late Medieval England: Private Piety and Public Performance (London: Routledge, 2000), 83-105. 
limits of the City, and the Clink manor in Southwark were notorious for fostering prostitutes and thieves. Although they did not have the same sanctuary status as claimed by St. Martin's and Westminster, their residents nonetheless were able to profit from their status as territories in or immediately neighboring the City, and yet outside the reach of London's sheriffs, mayor, aldermen, and their courts and guilds. ${ }^{13}$

Determining and recognizing the boundaries of such territories in the urban landscape were not straightforward matters. The bounds of St. Martin Le Grand's precinct were marked in some places by walls and gates, as one might expect, ${ }^{14}$ but in other places by notional, and not surprisingly often disputed, lines in the middle of streets. The limits were establishedalthough always contingently, never definitively - through social practice, its observation, and its recognition. Unlike some other English sanctuaries, where the immunity a sanctuary conferred acted as a kind of force field, strongest near the centre (the altar of the church), less secure at the edges, ${ }^{15}$ St. Martin Le Grand's urban situation made such gradations of sanctuary impracticable. Immunity at St. Martin's was all or nothing: a sanctuary seeker was either in, or out, of sanctuary, and the boundary, although disputed, had to be precise. The meaning of the sanctuary was constituted through claims, counterclaims, and royal confirmations; through precedent and custom; and through how particular kinds of individuals - those "privileged" of the sanctuary-inhabited and used a particular territory. Sanctuary men (and, much more rarely, women) lived, walked, stood, and drank - and were seen and remembered to live, walk, stand, and drink-in particular places and not others, and by so doing helped constitute the boundaries. ${ }^{16}$ Those boundaries were also observed, and sometimes challenged, by those outside the sanctuary, by neighbors, by passers-by, and by London civic officials. In such a way, the high concepts of the immunity of churches and the mercy of

13. See, for a graphic representation of the areas outside City jurisdiction, "The Wards c. 1520, including extra-parrochial areas," in Mary S. Lobel, The City of London From Prehistoric Times to c. 1520 (Oxford: Oxford University Press, 1989). See also Barron, London, 35-36; Penny Tucker, Law Courts and Lawyers in the City of London, 1300-1550 (Cambridge: Cambridge University Press, 2007), 43-45. Roberta Gilchrist's work on the precinct around Norwich Cathedral (Norwich Cathedral Close: The Evolution of the English Cathedral Landscape [Woodbridge: Boydell Press, 2005], esp. chapter 9) provides rich insights into monastic precinct boundaries as both symbolic of separation of sacred and secular and as jurisdictional markers.

14. Cf. Richard Grafton, Chronicle or History of England (London: J. Johnson, 1809), 2:225, http://www.archive.org/details/graftonschronicl02grafuoft (accessed Dec. 2, 2008); Kaufman, The "Polytyque Churche", 151-52.

15. Mazzinghi, Sanctuaries, 26-27; Shoemaker, "Sanctuary Law," 214.

16. This recalls Michel de Certeau's observations on "pedestrian speech acts," in Practice of Everyday Life, esp. 97-99. 
Christian kings were played out in the social practice and lived experience of late medieval Londoners.

In or around 1533, Francis Woodleke, an alien cordwainer and resident of the precinct of St. Martin Le Grand, decided to create a new shop window in the tenement he sublet. The tenement in which he lived and worked was on the east side of St. Martin's lane, right on the corner where the lane intersected with the street leading to Cheapside. The tenement up to that point had not opened onto the lane, however, but towards the other way, into what was called Pouchmaker's Court, inside the walled close of St. Martin Le Grand. On its west side the tenement backed onto a thick wall, built in the middle of the fifteenth century by the then dean of St. Martin's, Richard Caudray. Woodleke, probably looking for more passing trade, decided to break through that wall so that his shop window opened onto St. Martin's lane instead of into the close. He was not the first to have broken through the wall; in the early years of the sixteenth century another alien shoemaker named Harry Potts had done the same further north on the lane, apparently with no adverse effects. In 1516, John Browe, a pouchmaker and likely also an alien, leased a tenement at the same corner, probably next door to that later held by Woodleke; his shop also had windows out into St. Martin's lane, but Browe agreed by his lease to close the windows at the same time that St. Martin's great gate was closed and to hand over the keys to the constable until the gate opened again the following day. ${ }^{17}$ Woodleke, however, two decades later, was to find his windows on St. Martin's lane more problematic.

On a December afternoon in 1533, between two and three o'clock, the Chamberlain of the City of London, George Medley, accompanied by a constable and thirteen or fourteen other people, raided Woodleke's shop, as well as the shop of another cordwainer, George Colyn, living across from him in St. Martin's lane. Colyn had also opened a shop where there had not been one before, in a former back room of a tavern called the Bull's Head. Medley and the others carried away from the two shops into the custody of the City thirty-nine pairs of shoes and slippers and twenty pairs of boots. Woodleke and Colyn were alien craftsmen and as such, according to Medley, were prohibited from keeping any open shop to offer, buy, or

17. WAM, Westminster Abbey Register Book II, fols. 81v-82r. This tenement could, in fact, have been the same as Woodleke's, but on balance it seems more likely that Woodleke's was the tenement just to the north of this one, at this point held by Thomas Feryng alias Frez or Fryse. The lease on that tenement was taken up by Hugh Payne in 1527, and the tenement in which Woodleke lived was also sublet from Payne. Ibid., 23rv, 81v-82r, 234r; Will of Hugh Payne, 7 Oct. 1542, proved 26 June 1543, TNA, PCC, Prob. 11/29, fol. 173r. 


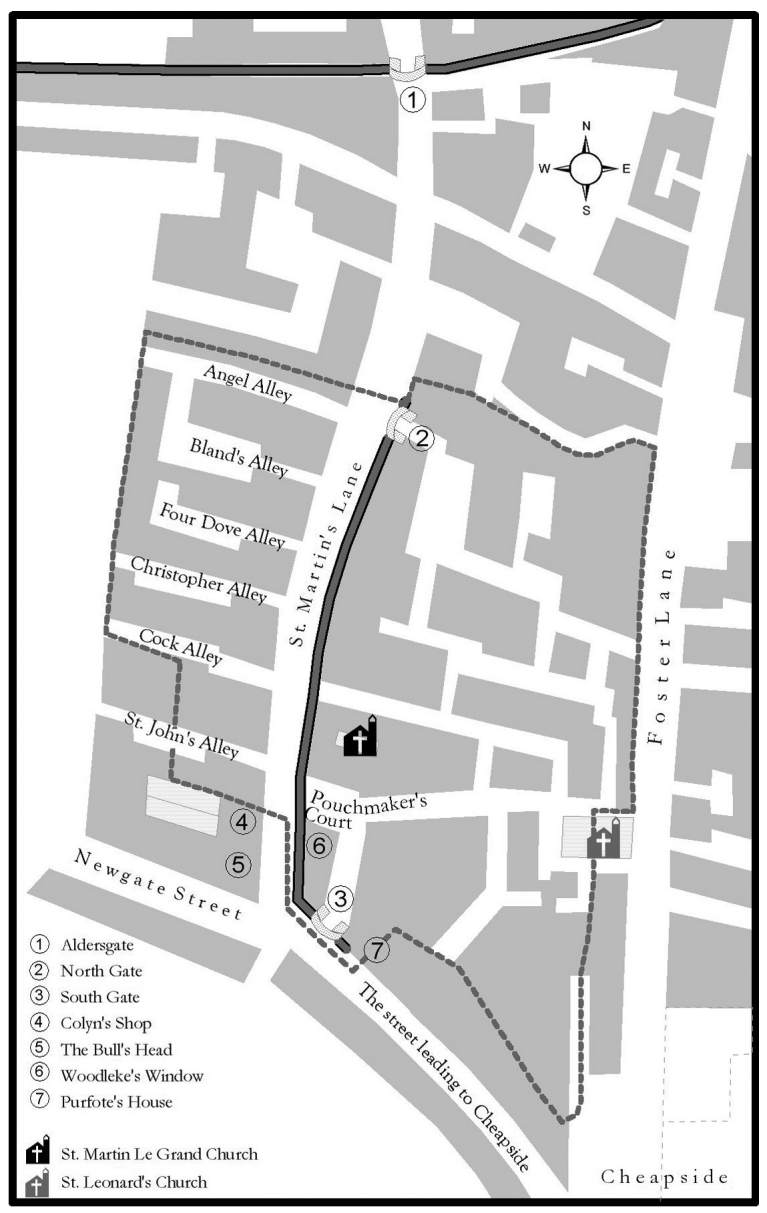

Figure 1. The Liberty of St. Martin Le Grand, c. 1536 (boundaries according to claims of the Abbot of Westminster, TNA, STAC 2/20/324).

sell any wares or merchandise in the City upon pain of forfeiture. Woodleke and Colyn, however, petitioned the king's minister Thomas Cromwell, claiming that their shops were in the precinct and liberty of St. Martin Le Grand and that the chamberlain thus had no jurisdiction there.

The rival claims of chamberlain Medley and the shoemakers were emblematic of long-standing disputes between the City and St. Martin Le Grand about precisely where the boundaries of sanctuary at St. Martin's lay and in particular the status of shops and tenements on St. Martin's lane. Previous alien craftsmen, such as Potts, had been able to maintain their shops in St. Martin's lane through claimed precedent and either explicit or implicit royal protection (some witnesses in a later dispute insinuated that 
Potts's boldness in breaking the wall was due to his having the patronage of Prince Arthur ${ }^{18}$ ). Woodleke and Colyn, however, had each tried to open new shops at a particularly sensitive time in the 1530s, when the events of the English Reformation were unfolding and the status of religious houses and their privileges was clearly in some doubt. Although Woodleke and Colyn presumably did not know this when they petitioned Thomas Cromwell regarding their problem, Cromwell was particularly opposed to sanctuaries and other ecclesiastical liberties, which he regarded as illegitimate encroachments on royal power. ${ }^{19}$ Although previous disputes between St. Martin's and the City had tended to be resolved in St. Martin's favor, in the 1530s the City had a much more receptive royal ear.

The case was decided in the City's favor. ${ }^{20}$ More importantly, Woodleke's breaking of the wall precipitated a broader inquiry into the extent and nature of the sanctuary at St. Martin Le Grand. As part of that inquiry, commissioned by the king in July 1535 to report to him in the Star Chamber, ${ }^{21}$ the City and the Abbot of Westminster each submitted statements of claim, citing precedents "proving" either that St. Martin's was not a sanctuary at all, but fully part and parcel of the City, or that St. Martin had an extensive and ancient privilege that included both the close around the church and both sides of St. Martin's lane. The roots of this quarrel between St. Martin's and the City extended back at least to the late fourteenth century; there were particularly heated episodes between 1430 and 1457, in the 1510s (including the Evil May Day antialien riots of 1517), and in the late 1520s. The latter disturbances (described by alien residents of St. Martin's precinct as violent and forcible attacks on their shops by agents of the City ${ }^{22}$ ) reflected City merchants' frustrations that the foreign shoemakers, pouchmakers, and other artisans of St. Martin Le Grand were exempted from legislation in the 1520 s restricting the taking of foreigners as apprentices and journeymen. ${ }^{23}$ Indeed, the specific claims and the general tone of the City's and the abbot's statements in the 1530s were remarkably similar both to the mid-fifteenth-century iteration of the dispute and to documents produced in

18. TNA, STAC 2/20/323, mm. 4, 27.

19. L\&P Henry VIII, 10:93, no. 254, http://www.british-history.ac.uk/report.aspx ?compid=75414 (accessed Dec. 2, 2008); G. R. Elton, Reform and Renewal: Thomas Cromwell and the Common Weal (Cambridge: Cambridge University Press, 1973), 135-38.

20. Or at least so the City's record of the case claims: LMA, Journal 13, fol. 420v. The 1542 will of Hugh Payne, the tenement's leaseholder, however, notes that "the Tenement dothe open into saint Martyns lane In which tenement oon Ffraunces Woodlake doth nowe inhabite and he hathe the same by leasse for certeyn yeres yet tocom." Will of Hugh Payne, PCC Prob. 11/29, fol. 173r.

21. LMA, Journal 13, fol. 453r.

22. TNA, STAC $2 / 29 / 198$ and $3 / 7 / 68$.

23. See Statutes of the Realm, 3:208-9, 297-98; TNA, STAC 2/29/198 and 3/7/68. 
1529 in the context of the more proximate quarrel, at least partly because in each case the parties relied on their own archives of documents deriving from the earlier disputes in marshalling their arguments. ${ }^{24}$ In addition to the abbot's and City's claims, more than two dozen witnesses, men who lived or had lived in the precinct and others from the neighborhood, were deposed regarding their knowledge and understanding of the sanctuary's boundaries and privilege. The witnesses, all male, were in many cases quite elderly, in their sixties and seventies, their testimony reaching back half a century and more in some cases. ${ }^{25}$ Much of the material I will discuss below comes from those depositions, preserved in the records of the Star Chamber, in which venue the commissioners reported their findings to the king and his council.

The terms of the commission, not to mention the broader context of the mid-1530s, made it unlikely that St. Martin's case would be accepted in its entirety, particularly as regarded its ecclesiastically based claims to immunity. Sanctuary privileges, under pressure from the judiciary from the 1510 s, ${ }^{26}$ had been somewhat limited by Parliament in 1534 and $1535-36,{ }^{27}$ and would be largely dismantled along with the dissolution of the royal free chapel of St. Martin Le Grand in $1542 .{ }^{28}$ Although the mid-1530s legislation was much milder than the more virulent critics of sanctuary must have wanted, in late 1536 and 1537, as the dissolutions of monastic houses proceeded, the future of ecclesiastical immunities and indeed the future of St. Martin Le Grand as a royal free chapel must have seemed precarious.

For some historians, the destruction of medieval sanctuaries has appeared inevitable, as the modernizing Tudor state both crushed the pretensions of

24. See for the 1440s and 1450s, WAM Book 5; TNA, C 49/68/15 and C/49/68/21; LMA, Journal 3, fols. 55v-65v; LMA, Letter Book K, fols. 298v-299r; for the late 1520s, LMA, Journal 13, fols. 186v-187r; 194r-196v; TNA, STAC 2/29/198 and 3/7/68.

25. Ralph Twyne, for instance, was only fifty years old, but noted that his knowledge of the customs of the precinct derived not only from his experience but also from his apprentice master, a certain Frist, who was in his eighties when Twyne had been apprenticed to him, and thus that his and Frist's accumulated memory went back about a century. TNA, STAC 2/23/266, mm. 56, 59.

26. Robert Keilway, Relationes quorundam casuum selectorum ex libris Roberti Keilwey (London: Thomas Wight, 1602; STC 14901), fols.188-92. Note that judicial concerns related primarily to extensions of the concept of permanent sanctuary to other religious houses such as St. John's Priory rather than to the concept of permanent sanctuary per se; cf. Ives, "Crime, Sanctuary," 296-303; Baker, "English Law of Sanctuary," 12; Baker, Spelman's Reports, 2:334-46, esp. 345.

27. Statutes of the Realm, 3:508-9, 551.

28. L\&P Hen. VIII, 17:396, no. 714/5, http://www.british-history.ac.uk/report.aspx ?compid=76667 (accessed Dec. 2, 2008). See the concluding section below on St. Martin's postdissolution history. 
a corrupt church and expanded the reach of royal power. ${ }^{29}$ We know that the witnesses who deposed in 1536 and 1537 were testifying about an institution about to undergo significant changes. They, however, did not know this. It is remarkable that the witnesses themselves-even those men called on the City's rather than the abbot's behalf-testified to a vibrant, working, if not entirely agreed-upon practice of sanctuary still wholly functional in the mid-1530s. The sanctuary's immunity, as the witnesses indicated in their testimony, was mapped through practice and observance onto the tenements, streets, gates, and walls of London.

Asylum-seekers entered sanctuaries such as St. Martin Le Grand through a process that involved their presentment before the Dean or his deputy, confession of the wrong that caused them to seek sanctuary, possibly the swearing of an oath to maintain good behavior and fidelity, ${ }^{30}$ and their relinquishment of all weapons save only a "poyntlese" knife to carve meat. ${ }^{31}$ This formal process may have been confined to those who sought sanctuary as accused felons; the particular restrictions on sanctuary dwellers and the precise meanings of the boundaries they observed varied according to the reasons they had sought entry. Felons, political refugees, and debtors had to remain strictly within the geographical bounds of the sanctuary, or they were liable to be seized by arresting officials, political opponents, or creditors. In some cases, the accused felons were apparently placed in a prison under the care of the constable of St. Martin Le Grand, ${ }^{32}$ although witnesses' descriptions of such felons walking through the precinct on a daily basis suggests this was by no means always the case. In 1525, two royal commissioners named as "prisoners within St. Martin's Sanctuary" eleven men and one woman, five of whom were specified to be felons or murderers, one a trespasser, and one a debtor, ${ }^{33}$ judging by this list-how complete, we have no way of knowing — felonious sanctuary seekers may

29. See especially Thornley; the historiography is discussed below.

30. Such an oath is transcribed in Sanctuarium Dunelmense et Sanctuarium Bevercalense (London: J. B. Nichols and Son, 1837), 111, http://books.google.com/books?id= ySc8AAAAIAAJ\&pg=PA111\&source=gbs_toc_r\&cad=0_0 (accessed Dec. 2, 2008).

31. LMA, Letter Book K, fol. 298v.

32. During the 1520s and 1530s (and possibly before that), the constable of the precinct was a man named Hugh Payne, who also held the leases of many of the properties in the precinct, subletting them to others. TNA, STAC 2/21/121; L\&P Hen.VIII, 2/2:1466, http://www .british-history.ac.uk/report.aspx? compid=90980 (accessed Dec. 2, 2008); 2/2:1469, http:// www.british-history.ac.uk/report.aspx?compid=90981 (accessed Dec. 2, 2008); 2/2:1471, http://www.british-history.ac.uk/report.aspx?compid=90982 (accessed Dec. 2, 2008); Westminster Abbey Library, Westminster Abbey Register Book II, 1509-36 (typescript calendar), fols. 15, 23rv, 188v-189r, 234r.

33. L\&P Hen. VIII, 4/1:473, no. 1082, http://www.british-history.ac.uk/report.aspx?compid $=91222$ (accessed Dec. 2, 2008). 
not have been great in number in St. Martin's. Alien craftsmen and their households, on the other hand, were almost certainly the majority of inhabitants in the liberty. They were likely freer to leave the precinct-it was the practice of their trade and the selling of their goods into the City that was prohibited, rather than their actual bodies. Many sanctuary dwellers, especially aliens and debtors, operated shops in the precinct, exempt both from London's guild system and from the seizure of goods for debt.

If many sanctuary dwellers had to stay within the precinct, the sanctuary boundary was entirely permeable in the other direction: anyone could enter into the precinct. Merchants and victuallers of the City of London, for instance, provided the inhabitants with goods, food, and drink. The profits for those merchants could be considerable, as prices were high: the scribe William Ebesham wrote to his patron Sir John Paston in 1468, complaining about the "grete coste" of living in sanctuary, "amonges right vnresonable askers." ${ }^{34}$ Those profits, however, had to be weighed against the difficulties for City merchants in enforcing payment for these goods, as those delinquent on their bills could not be hauled into the City courts. ${ }^{35}$

Although much of the scholarship on English sanctuary has assumed that the privileges of sanctuary focused on felons fleeing criminal justice, by the fifteenth and sixteenth centuries, as contemporaries knew, most sanctuary dwellers were alien craftsmen rather than criminals. The opposition of the City of London to the privileges of St. Martin Le Grand was perhaps most inflamed by those craftsmen and debtors, whose flight harmed and compromised City jurisdiction over the crafts and over suits for debt. The City and other opponents of sanctuary understood, however, the rhetorical value of invoking "the enorme enymyes of god," 36 or, as Sir Thomas More put it, the "rabble of theues, murtherers, and maliciuos heyghnous Traitours," ${ }^{37}$ in their attacks on St. Martin Le Grand. And indeed for the

\section{Davis, Paston Letters, 2:387.}

35. In 1402, the Commons presented a bill on behalf of London merchants, who complained about the iniquities, unfaithfulness, and disruptions to proper order in the City of London perpetrated by those living in St. Martin Le Grand. "The inhabitants of the said college often deceitfully send various persons of their affinity to merchants and victuallers of the same city to buy various wares, merchandise and victuals, telling them that they should arrange for the same wares, merchandise and victuals to be brought to the same college in order to have immediate payment there. Yet once these wares, merchandise and victuals have been brought there, the said vendors are unable to recover them to get payment for them." Chris Given-Wilson, ed., The Parliament Rolls of Medieval England [PROME] (Leicester: Scholarly Digital Editions, 2005), 3:503-4.

36. See, for instance, TNA, STAC 2/20/324, mm. 3-8 (quotation at m. 5); see also LMA, Journal 13, fol. 467r.

37. Thomas More, "The Historie of kyng Rycharde the thirde," in The Workes of Sir Thomas More Knyght (London: Rastell, 1557; STC 18076), 47. 
sanctuary dwellers themselves who gave depositions to the Star Chamber inquiry in the mid-1530s - all alien craftsmen - the few men who dwelled in St. Martin Le Grand as accused felons were the most notable exemplars of the "sanctuary man." As we will see below, the safety of a notorious murderer or a conspirator in a plot against the king within the confines of the sanctuary was the most vivid proof in their minds of St. Martin's privileges.

The testimony in the Star Chamber inquiry in 1536-37 centered on the precise extent of the sanctuary's boundaries. When examined, the witnesses evidently responded to leading questions from their examiners ${ }^{38}$ probably derived from the statements of claim submitted by the abbot and the mayor and aldermen of London. ${ }^{39}$ In his statement, the abbot took his listeners on a verbal walking of the bounds:

From the seid seynt Martyns lane att the foreseid Bulle hedde turnyng by a walle that deuydethe the said tenemente of the Bulle hedde and seynt martyns grounde which walle turneth and extendyth ffrom the est Westwardis vnto the backe walle that closeth in seynt Martyns grounde of the West syde, all withyn the seid wall seyntwary.

Item alonge by the same back wall that closeth in the West parte of seynt Martyns ground from the south ende of the seid walle into the Northe vnto a wall ... .40

The commissioners evidently read the abbot's statement to the deponents and asked for their comments. Whether agreeing with the abbot's claim or not, the witnesses took the same pedestrian approach to describing the topography of the neighborhood; their conceptualization of urban space was notably different from our own. ${ }^{41}$ For a modern reader, the abbot's and the deponents' descriptions have us reaching for a pad of paper to sketch a map representing the space from a bird's eye perspective. ${ }^{42}$ The abbot may in fact have ordered such a diagram to be made as part of his submission;

38. The examiners were Henry Polsted (a servant of Cromwell) (TNA, STAC 2/23/266, m. 1; L\&P Henry VIII, 10:93, no. 254, http://www.british-history.ac.uk/report.aspx?compid=75414 [accessed Dec. 2, 2008], 10:432, no. 1039, http://www.british-history.ac.uk/report.aspx ?compid=75435 [accessed Dec. 2, 2008]) and John Croke, a Chancery official (TNA, STAC 2/20/323; J. H. Baker, "Croke, John [1489-1554]," in Oxford Dictionary of National Biography [ODNB], ed. H. C. G. Matthew and Brian Harrison [Oxford: OUP, 2004], http://www .oxforddnb.com/view/article/6732 [accessed May 29, 2007]).

39. TNA, STAC $2 / 20 / 324$.

40. TNA, STAC $2 / 20 / 324$, m. 2.

41. See Daniel Lord Smail, Imaginary Cartographies: Possession and Identity in Late Medieval Marseille (Ithaca: Cornell University Press, 2000), esp. 1-8.

42. See, on other graphic representations of the sanctuary, Honeybourne, "Sanctuary Boundaries," 324-25; Honeybourne herself creates a map based on the abbot's submission. Ibid., 334 . 
John Strype in 1720 reproduced a now-disappeared "plat" of the precinct which he associates with the abbots' submissions in 1536, a crude and rather unsuccessful map. ${ }^{43}$ As Marjorie Honeybourne commented in the 1930s, the "draughtsmanship was weak," with too many irregular angles converted to right angles and the proportions inaccurate. ${ }^{44}$ For interested parties and observers in the 1530 s, a pedestrian perspective was clearly much more precise.

The boundaries described by the witnesses for both parties were defined by custom, by usage, and in some cases by physical boundary markers such as walls or posts, or the memories of markers that had once been there. In the case of a boundary post that had stood by the North Gate of St. Martin's close until "vnknowen persones" had pulled it down about $1534,{ }^{45}$ for instance, it was the memory of the physical marker that had once been there that for some marked the northern limit of the sanctuary. Even in cases where the boundaries were marked in a physical sense, though, those barriers did not in the sixteenth century generally function as real barriers to ingress or egress, but as notional borders, generally agreed-upon conventions that on one side lay the City, on the other lay sanctuary, with all the legal and political implications that accompanied that distinction. The walls, for instance, were often in a state of considerable disrepair, but witnesses were at pains to insist that, despite their crumbling or even having fallen down altogether, the walls or the lines they had once followed were still visible and thus they continued to function as clear indications of the boundaries. ${ }^{46}$

The precise limits of the sanctuary were, of course, in dispute. Although the City attempted to make the argument that the sanctuary simply did not exist and had never existed, ${ }^{47}$ even the witnesses called on behalf of the City agreed that certain parts of the territory pertaining to St. Martin's functioned as sanctuary. Although there were certain places that many witnesses could not definitively declare to be either sanctuary or not-as we will see below-the main line of division was between those who limited sanctuary to the walled close around the church of St. Martin, north of the

43. John Strype, A survey of the cities of London and Westminster, vol. 1, bk. 3 (London: A. Churchill, 1720), 110; the map is also reproduced in Honeybourne, "Sanctuary Boundaries," 333.

44. Honeybourne, "Sanctuary Boundaries," 324-25.

45. Deposition of Piers Peterson, TNA, STAC $2 / 23 / 266, \mathrm{~m} 2$; this was mentioned by a number of deponents, e.g. mm. 11, 15, 18, 33, 37, 41, 43, 55, 60 .

46. Rowland Johnson deposed, for instance, that "about saint Leonardis churche and so from thens to the said Roger Wrightis house [the wall] is downe and broken in many places Albe it he saieth that the bound therof may be well Inough perceyued." TNA, STAC 2/23/266, m. 12.

47. TNA, STAC 2/20/324, mm. 3-8. 
street leading to Cheapside and between St. Martin's lane on the west and Foster lane on the east; and those who supported the abbot's claim that sanctuary extended to certain tenements leased from the abbey and from the Earl of Northumberland on both sides of St. Martin's lane itself.

The former argument-limiting the privileges to the walled precincthad both a certain logic and historical precedent behind it. A number of the deponents who testified on behalf of the City in 1536 recalled that in the fifteenth century the area around St. Martin's church had been enclosed by a wall, with two or three gates (the number differed according to the deponent) and the west door of St. Martin's church as the only points of entry and exit. One witness remembered that the name of the fifteenthcentury dean who had erected the wall, Richard Caudray, was engraved upon it. ${ }^{48}$ Regulations established by the king and council at the tail end of the mid-fifteenth-century dispute between the City and St. Martin Le Grand, in $1457,{ }^{49}$ suggest that the sanctuary was indeed at that time confined to the walled area of the close. Those regulations mandated that all gates and postern doors or any other means of egress from the sanctuary be closed and shut nightly at nine o'clock, to remain closed until six o'clock in the morning from All Hallow's Eve until Candlemas (February 2), and in the rest of the year until four in the morning or the beginning of the first mass. All who had fled into the sanctuary "for treason or felonye" were to be within the closure at nighttime (implying they were allowed further afield during the day?).

A number of witnesses in 1536 argued that this area within the wall functioned as a kind of natural integral territory, with gates that, of old, had closed at curfew, marking a clear boundary, both spatially and temporally, between in-sanctuary and out-of-sanctuary. George Isotson told a story of a hermit of Islington to corroborate his claim that only the area within the close was sanctuary. He knew a man named Robert, now a hermit at Islington, who had been a prisoner at the Marshalsea or King's Bench prison. He had escaped from the prison (so Isotson had heard) and made his way in the middle of the night to St. Martin Le Grand, with irons still upon his legs. Because he could not get in "for that the gates were so well kepte and shutt in, he laye or stode, by reporte, harde at the southgate of the sayd saynt Martyns vntyll the mornyng that the gates were oponed

48. Deposition of Piers Peterson, TNA, STAC 2/23/266, m. 6.

49. The 1457 articles survive in a number of forms. The City of London recorded the articles in Letter Book K, fols. 298v-299r (the version transcribed here). A fragment of the regulations is preserved in a document among the Exchequer records: Kew, TNA, E 135/23/49. Kempe transcribes in full a version that likely derives from Lansdowne MS 170 in the British Library, although Kempe does not give his source. Kempe, Historical Notices, 146-51, this clause $148-49$. 
and then entred and tooke seyntuary there." Robert the future hermit did not trust attempting to take sanctuary in any part of St. Martin's lane; he knew that truly safe sanctuary could only be within the gates. ${ }^{50}$

But even though these witnesses argued that the sanctuary should be confined to the close, they virtually all recognized that the tenements and shops on St. Martin's lane- on both sides_-were also commonly used and recognized as sanctuary. If the City's witnesses argued that breaking of the sanctuary wall on the east side was an illicit innovation of the relatively recent past, the abbot's witnesses could wield the weapon of custom, too: they remembered famous sanctuary seekers of the fifteenth century living on the west side of St. Martin's lane. John Smith, canon of St Paul's and commissary of St. Martin Le Grand from the 1480s until 1503, recalled that John Morton, then bishop of Ely and ardent Lancastrian, later Henry VII's cardinal archbishop of Canterbury, took refuge in St. Martin Le Grand during the Wars of the Roses. Morton, as Smyth remembered, stayed in Angel Alley. ${ }^{51}$ Two deponents recalled that a man named Bland, an associate of Perkin Warbeck, whose rebellion against Henry VII was crushed in 1497, had also lived in St. Martin's as a sanctuary man for twenty years, staying in Bland's Alley. ${ }^{52}$ And, although neither the abbot nor his witnesses raised this point, in the 1460s and 1470s, Edward IV specifically named both sides of St. Martin's lane as part of the liberty of St. Martin Le Grand when he exempted St. Martin's from certain pieces of economic legislation in recognition of that status as a liberty. ${ }^{53}$ Similarly, the 1525

50. Deposition of George Isotson, TNA, STAC 2/20/323, mm. 29-30.

51. Deposition of John Smith, TNA, STAC 2/23/266, m. 68. A 1470 letter from John III Paston to his mother confirms Smyth's memory - "the Bysheop of Ely wyth othyr bisheopys ar in Seynt Martyns" (Norman Davis, ed., The Paston Letters and Papers of the Fifteenth Century [Oxford: Clarendon Press, 1971, 1976], 564)—although it is also worth noting that John Smith would have been only about nine years old at the time.

52. Witness Raff Twynne spoke of "oone Blande which was a Sentuary man and had contynued in Sentuary xx years and first he dwelt in Coke Aley and afterward in the Brodgate which is nowe called Blandis Aley." Deposition of Ralph Twynn, TNA, STAC 2/23/266, mm 57-58; see also deposition of William Baylyn in ibid., m. 64. The name "Bland's Alley" is not recorded until 1525, according to Henry A. Harben's A Dictionary of London (1918), http://www.british-history.ac.uk/report.asp?compid=63038 (accessed June 6, 2007), suggesting that the alley may well have been named for this semifamous inhabitant.

53. E.g. "Provided also that neither this ordinance and act, nor any other ordinance, statute or act made or to be made in this present parliament, shall extend or be prejudicial or harmful in any way to Robert Stillington, clerk, dean of the king's free chapel of St. Martin Le Grand of London, or to his successors the future deans of the said chapel, or to the said Robert, the dean, and the chapter of the same chapel, with regard to all the privileges, liberties, franchises, rights and customs pertaining to them in any way before the same parliament; or to any person or persons dwelling or living, or who shall dwell or live in future, within the sanctuary and precinct of the same chapel, and particularly within the lane commonly called St. Martins Lane." Given-Wilson, PROME, 5:507 (emphasis added), see also 5:510, 566; 6:187. 
certificate of "prisoners within St. Martin's sanctuary" included sanctuary men living in Bland's Alley and Cock's Alley. ${ }^{54}$ Witnesses for the mayor and aldermen, on the other hand, claimed that the west side of St. Martin's lane was fully part of Aldersgate ward, and some witnesses claimed that as ward officials they themselves had searched in the lane and assessed its inhabitants in the king's subsidies along with the rest of the ward. It was treated as in City jurisdiction-therefore it must have been. ${ }^{55}$

Even the abbot himself, however, did not include the entire length of St. Martin's lane as sanctuary territory. ${ }^{56}$ There was a good deal of ambiguity, however, about precisely where the dividing line between sanctuary and not-sanctuary lay. The tavern at the southwest corner of the lane, called the Bull's Head, was recognized by all as being within the freedom of the City. The status of a small tenement erected on the property behind the tavern was, however, less clear. By December 1533, the tenement had become a shoemaker's shop - the shop of George Colyn, alien cordwainer, which had been raided by London's chamberlain in 1533 along with Francis Woodleke's shop. This conversion to shoe shop was a relatively recent one, however; for some time before, according to many witnesses, it had been and was mostly still known as the "sanctuary parlor," a back drinking room connected to the Bull Head tavern. Piers Peterson, who had lived in sanctuary on the messuage next door from $1514^{57}$ (and who, according to civic records, had helped London's chamberlain raid Colyn's and Woodleke's shops ${ }^{58}$ - a detail he did not reveal in his depositions two years later), argued "for troth" that the sanctuary parlor was not and never had been sanctuary. He had seen many sanctuary men arrested and taken out of the parlor; moreover, he added, "he herd saye that hit was found by twelf men afore the kingis Justices that the said parlor was no Sanctuary." ${ }^{59}$ A number of witnesses

54. L\&P Hen. VIII, 4/1:473, no. 1082, http://www.british-history.ac.uk/report.aspx?compid= 91222 (accessed Dec. 2, 2008).

55. Subsidy records from a 1536 subsidy collection for Aldersgate ward do indicate that several inhabitants of the precinct who either deposed or were cited by deponents in the 1536-37 enquiry, including Francis Woodleke, were assessed in 1536 (TNA, E 179/144/109). Other pre-dissolution subsidy collection records for Aldersgate ward, however, suggest that this may have been unusual (possibly connected with this dispute). The only 1536-37 witnesses listed in the 1541 subsidy rolls, for instance, are two who clearly lived outside the precinct, Raphael Cornish and John May. TNA, STAC 2/20/323, mm. 10-16; R. G. Lang, ed., Two Tudor Subsidy Rolls for the City of London: 1541 and 1582 (London: London Record Society, 1993), 1-9, http://www.british-history.ac.uk/report.asp?compid=36095 (accessed June 6, 2007).

56. TNA, STAC 2/20/324, "Declarations of the Abbot of Westminster and the Mayor and Aldermen of London regarding the limits of the sanctuary of Saint Martin-le-Grand," m.2.

57. Westminster Abbey Register Book II, fol. 64rv.

58. LMA, Journal 13, fol. 420v.

59. TNA, STAC, 2/23/266, m. 5. 
agreed with Peterson, ${ }^{60}$ but others suggested that the status of this former drinking parlor was less certain, as indeed Peterson's own story about the number of sanctuary men who drank there suggested: as Cornelys Hobbard said, he had known many sanctuary men to drink in the parlor, but he had also seen many such sanctuary men arrested there and carried off to prison, so he was not sure whether it was sanctuary or not. ${ }^{61}$

John Smith, the former commissary of St. Martin's, offered some intriguing evidence about the sanctuary parlor and how the boundaries could be observed. He testified that although on the whole he did not think that the sanctuary parlor was sanctuary, nonetheless "he hath seen Sanctuary men vse to drinke in the saide parlour and accompted them selfis in Sentuary so long as they touched the saide wall that parteth the abbotis rentis and the bulhed grounde." ${ }^{\prime 2}$ At some point this "home safe" wall touching seems to have been ruled out of order, however, as by the 1530s, only two witnesses unambiguously claimed the sanctuary parlor as sanctuary. ${ }^{63}$ The abbot himself implicitly excluded the shop in his own statement regarding the bounds of the precinct, ${ }^{64}$ and one witness reported that when the abbot had taken an official view of the boundaries of sanctuary in the earlier 1530s, he had given "monycion that the sanctuary men shulde not resorte therer but at theyre parylle." 65

Witnesses on both sides recalled, usually in vague terms, an episode of a sanctuary man being dragged out of the sanctuary parlor by servants of the sheriffs of London, a story told in greatest detail by deponent John Curteys. He said that "of late days" a certain man who had stolen a silver piece out of the Sun tavern at Cripplegate and subsequently took sanctuary at St. Martin's for that felony, afterwards used to resort to the sanctuary parlor. One day, however, officers of the sheriffs of London heard that he was drinking there, and took him out of the parlor and conveyed him through the said Bull Head tavern onto Newgate street and to Newgate prison. Soon after that, the thief was executed for his felony. ${ }^{66}$ This man paid the price of not understanding that some parts

60. E.g., TNA, STAC 2/23/266, mm. 8-9, 15 .

61. Deposition of Cornelys Hobbard, TNA, STAC 2/23/266, mm. 19-20; see also mm. 21, 32, 36, 39, 64 .

62. Deposition of John Smith, 28 Dec. 1536, TNA, STAC 2/23/266, mm. 67-68.

63. George Hayes testified that the shoemaker's shop "as ffer as he knoweth" is sanctuary, for sanctuary men used to drink there when it was a tavern; and Henry Hall more straightforwardly said that it "hath ben euer vsed as sanctuary." TNA, STAC 2/23/266, mm. 44, $54-55$.

64. The abbot places the boundary of the sanctuary north of "the howses apperteynyng to the Bullis Hedde," presumably including the sanctuary parlor. TNA, STAC 2/20/324, m. 2.

65. Deposition of Roger Wright, TNA, STAC 2/20/323, m. 7.

66. Deposition of John Curteys, TNA, STAC 2/20/323, m. 26-27. The claim submitted by 
of St. Martin's lane were safe, others not; clearly understanding where the boundaries lay was (literally) vital, and cautionary tales such as this one, perhaps repeated over ale, warned sanctuary men which areas were safe and which not.

It is hardly surprising that the Sun tavern thief would have misunderstood the status of the sanctuary parlor, as the lines allegedly demarcating the sanctuary along the bottom part of St. Martin's lane were unquestionably recondite. The abbot and those testifying on his behalf argued that while both sides of St. Martin's lane were sanctuary through most of the lane, from the northernmost wall of the Bull Head tenement, the sanctuary bounds ran on a notional line perpendicular to the street up to the drainage channel in the middle of the St. Martin's lane and then south to the corner of the lane. Witnesses testified that sanctuary men walking down St. Martin's lane were careful to keep to the east side of the street when they reached its south end. Ralph Twyn noted that Bland, the Perkin Warbeck conspirator, would follow this pattern; when he walked up St. Martin's lane, he sometimes went on one side of the street and sometimes on the other, until he came to the Bull Head ground, "which was then called the Sentuary parlor," and at that point "he wolde alweys turne ouer the strete and go on the side, that is vnder ffrauncis Goodlakis said shop windowe, and wold neuer go on the Bullhed side." ${ }^{67}$

As Bland's customary walking pattern suggests, one means of delineating sanctuary territory was through remembrance of who walked, stood, leaned, drank, or lived, where. Bartholomew Watson, in arguing that St. Martin's lane had not been considered sanctuary in the years around 1500, testified that about thirty years before he had seen two sanctuary men leaning against the sides of the door of the west end of St. Martin's church. They talked with passersby, but they "durst not steppe or goo any further ynto the sayd lane leste that they shulde haue byn owt of sanctuary." ${ }^{\circ 8}$ Derek Tymhollf said that he had seen many sanctuary men leaning upon the old post that had stood beneath the north gate, which marked the bounds of the sanctuary. ${ }^{69}$ William Mathew testified in 1537 that he had known a man named

\footnotetext{
the mayor and aldermen gave further details about what was probably the same case: "Item In the tyme of Sir James Spencer Mair anno vicesimo Henrici viii ${ }^{\text {ui }}$ [1528-29] Judgement was geven at Newgate ageynst one Griffith who pledyd Seyntuary for that he was forceably takyn oute of a house in the lane of seynt Martyn and the same ffounde no seyntwary by the veredicte of xii men and the prisoner Judged to death and hanged." TNA, STAC 2/20/324, m. 8 .

67. Deposition of Ralph Twyn, TNA, STAC 2/23/266, m. 58.

68. Deposition of Bartholomew Watson, TNA, STAC 2/20/323, m. 5.

69. This phrase is in the summarized version; Deposition of Derek Tynholff, TNA, STAC 2/20/57, m. 9 .
} 
Seyntbarbe who had been a sanctuary man, a retainer of the Perkin Warbeck conspirator Lord Audeley, ${ }^{70}$ who had escaped from Blackheath field in 1497 to St. Martin's. When Mathew was an apprentice, Seyntbarbe would often resort to the shop of his master and stand inside the South Gate of St. Martin's close, talking and communing with those who passed by in the street. Neither of these things, "as the deponent supposeth," could he have done had the area not been sanctuary. Likewise, Mathew's master's house was evidently sanctuary territory because his master had been a "Sentuary man"; thus he would not, could not "haue dwellyd there oneles that place had byn seyntuary." 71

William Mathew's master's house was on a street apparently with no contemporary name ${ }^{72}$ but which the witnesses called "the street leading to Cheapside," around the corner from Francis Woodleke's shop. On this street stood the South Gate into St. Martin's close. Both the marking of the sanctuary bounds outside the gate and the status of Mathew's apprentice-master's house, just east of the gate, were at least as complicated as the lower part of St. Martin's lane. Just as with the lane, at least some witnesses claimed that a line down the middle of the road along the drainage channel marked the boundary on the street leading to Cheapside. This was illustrated most vividly in the minds of many deponents by the spatial organization of proceedings held before the king's justices at St. Martin's Gate.

From at least the thirteenth century, the king's justices had held proceedings at St. Martin's gate, both in cases where an error in one of the City's higher courts was alleged, ${ }^{73}$ and at nisi prius (where justices, for convenience, heard proceedings on issues, both criminal and civil, referred to them by the central royal courts, but did not render judgments ${ }^{74}$ ). This practice originated in order to guard the City's privileges against royal encroachment: St. Martin's was outside City territory, yet conveniently placed geographically in the midst of the city. ${ }^{75}$ But if the justices had

70. Ian Arthurson, "Tuchet, James, seventh Baron Audley (c.1463-1497)," in $O D N B$, http://www.oxforddnb.com/view/article/27576 (accessed June 8, 2007).

71. TNA, STAC 2/20/323, m. 21.

72. By 1600 it was called Bladder Street. John Stow, A Survey of London, ed. Charles Lethbridge Kingsford (Oxford: Clarendon Press, 1908), 313, http://www.archive.org/details/ asurveylondon00stowgoog (accessed Dec. 2, 2008).

73. J. H. Baker, The Oxford History of the Laws of England, vol. 6, 1485-1558 (Oxford: Oxford University Press, 2003), 279, 403-7; Tucker, Law Courts, 39-40.

74. Baker, Oxford History, vol. 6, 256-59.

75. Reginald R. Sharpe, ed., Calendar of Letter-Books Preserved among the Archives of the Corporation of the City of London at the Guildhall [CLB] (London: J. E. Francis, 1899-1912), $C L B A, 213$, http://www.british-history.ac.uk/report.aspx?compid=33031\#s11 (accessed Dec. 2, 2008); $C L B F, 59-60$, http://www.british-history.ac.uk/report.aspx?compid=33532\#s18 (accessed Dec. 2, 2008), 64, http://www.british-history.ac.uk/report.aspx?compid=33533\#s10 
to be outside the City's bounds, any accused wrongdoers being tried at nisi prius could not be within the liberty of St. Martin Le Grand, or they could claim sanctuary. In 1440, the Dean of St. Martin Le Grand, Richard Caudray, claimed in asserting the rights of St. Martin's against a challenge that had been launched by the sheriffs of London, that "fro tyme pt no mynde is" the king's justices had sat in the gate, and the persons appeached or indicted of treason or felony were kept by the officers on the further side of the street before them, so that they could not come over the other side of the drainage channel to claim sanctuary. ${ }^{76}$ Witnesses in the $1530 \mathrm{~s}$ testified to the continuity of this practice, Roger Wright recalling that when the king's justices sat at the gate of St. Martin's, the gate was shut and a cloth hung over the gate with the justices' seats leaning towards the gate. He saw one Appulton, a barber, arraigned, and at the time of his arraignment Appulton stood on the other side of the street at a bar made there for that purpose. ${ }^{77}$ Indeed, one deponent, William Bayllys, testified "that he hard the cheiff justice say that the halffe strete towardis seynt Martyns was seyntwarye." 78 The prisoners' bar-about which a number of deponents testified $^{79}$ - was presumably erected temporarily, for the purposes of the judicial proceedings. It marked more clearly the boundary that otherwise was indicated only by the drainage channel, and perhaps even served to physically restrain the prisoners from putting their foot over the line.

No deponents referred to any instance of a prisoner being tried before the justices at St. Martin's gate making this escape into sanctuary. There had been some notorious cases in the fifteenth century, however, of prisoners being led along the street leading to or from Newgate prison escaping through St. Martin's gate to safety. In 1440, for instance, an accused felon

(accessed Dec. 2, 2008), 89, http://www.british-history.ac.uk/report.aspx?compid=33535\#s11 (accessed Dec. 2, 2008), 106, http://www.british-history.ac.uk/report.aspx?compid=33536\#s20 (accessed Dec. 2, 2008); $C L B G, 83,86$, http://www.british-history.ac.uk/report.aspx?compid= 33496 (accessed Dec. 2, 2008); Barron, London, 37; Baker, Oxford History, vol. 6, 279.

76. WAM Book 5, fol. 48r.

77. Deposition of Roger Wright, TNA, STAC 2/20/323, m. 9.

78. TNA, STAC $2 / 20 / 57, \mathrm{~m}$. 13. Interestingly, that chief justice was possibly Sir John Fyneux, named by another deponent as presiding over proceedings at St. Martin's gate (TNA, STAC 2/20/323, m. 22). Fyneux, chief justice of the King's Bench from 1495 until his death in 1525 , is sometimes cited as a judicial opponent of sanctuary privileges (J. H. Baker, "Fyneux , Sir John [d. 1525]," in $O D N B$, http://www.oxforddnb.com/view/article/10261 [accessed September 9, 2008]; Baker, Oxford History, vol. 6, 548-49; Thornley, "Destruction of Sanctuary," 198). Fyneux's objection to some sanctuaries may not have extended, however, to St. Martin's, as St. Martin's met his requirements for a properly constituted sanctuary: royal grant, papal confirmation, and use before legal memory, supported by royal confirmation and use since. Keilway, Relationes, fols.188-192, esp. fol. 190.

79. TNA, STAC 2/20/323, m. 22; STAC 2/23/266, mm. 4, 28, 49. 
was being led by one of the sheriff's servants from Newgate to the Guildhall for jail delivery. As they passed just to the east of St. Martin's lane, five men reportedly rushed out, attacked the sheriff's servant with daggers drawn, and dragged the prisoner into St. Martin's lane and ultimately the church and undisputed sanctuary. ${ }^{80}$ As a precaution, and in parallel to the sanctuary men who were careful to walk on the sanctuary side of the street, Roger Newes reported in 1536 "all they which cumme from the Tower to be put to execucion at Tyburne and all other prisoners which ar brought to or from Newgate ben alweys caried on the fferther side of the strete from the said Southgate that is to saye on the South side of the strete for ayenst the same gate." ${ }^{\prime 1}$ To further corroborate the importance of keeping the felons away from the sanctuary side of the street, deponent Derek Tynholf remembered the aftermath of the 1517 Evil May Day antiforeigner riot, a riot in which the aliens resident in St. Martin Le Grand were a particular target: "when yll may daye was, ther was a pair of galowes set vp at saint Martens Southgate in the strete where oone shulde haue ben put to execucion, whiche galowes were afterward remoued bicause they stode vpon the Sentuary ground, [and] were set on the ferther side of the strete ouer right again saint Martens gate. And the man was hanged." 82

The notional line down the middle of the street outside the South Gate did not extend all the way down the road to Cheapside but stopped partway across the tenement on the gate's east side, formerly held by William Mathew's apprentice-master and held in the 1530s by Roger Wright, a grocer. As many deponents testified, Wright's house had a great post in the middle that marked the sanctuary bounds. One side of the house was sanctuary, the other side, City of London. Wright himself was not a sanctuary man, but a citizen and grocer, and thus the house's status as part-sanctuary was neither here nor there to him..$^{83}$ The strange status of Wright's house owed its origins to a previous tenant, Robert Purfote, a citizen and grocer

80. Kempe, Historical Notices, 117. A prisoner being transported from the Tower to the Marshalsea in 1534 escaped into sanctuary in a parish church. J. H. Baker, ed., The Reports of Sir John Spelman (London: Selden Society, 1977, 1978), 1:52.

81. Deposition of Roger Newes, TNA, STAC 2/23/266, m. 28.

82. Deposition of Derek Tynholf, TNA, STAC 2/23/266, m. 39.

83. "He harde saye that the one halff of hys sayd howse that ys to saye that parte next adioynyng to the sayd gate hathe byn takyn for saynctuary belongyng to saynt Martyns ynsomoche that the olde Abbot of Westm' abowt vi or vii yeres passed dyd viewe yn hys owne persone the sayd howse and dyuerse other howses yn saynt Martyns lane at whiche tyme the sayd Abbot sayed and reported to thys deponent and other there present that the saynttuary dyd extende to a great post on the southe parte of the sayd howse whyche stode some tyme yn a particion withyn the same howse and whiche particion dyd extende northwarde vnto the ende of one olde walle there yet remaynyng." Deposition of Roger Wright, TNA, STAC 2/20/323, m. 6. 
who had taken sanctuary for debt in the later part of the fifteenth century and had been William Mathew's apprentice-master. Mathew testified both in 1536 and 1537 regarding the sanctuary's bounds, and offered his special knowledge of the house from his experience of living in Purfote's household in the $1490 \mathrm{~s} .{ }^{84}$ Purfote became tenant of the house immediately on the east side of the South Gate when he went into sanctuary for debt, some time in the 1470s or 1480s ${ }^{85}$ The door of the house opened through the gate, thus directly into sanctuary. Although, as witness John Marten put it, "Purfote bicause he was a Sentuary man might not be suffred to open any dore into the strete," nonetheless "bycause he was a ffreman he was suffred to open his shop windowes into the strete" so that he could sell his goods into the City - the customers would be standing in the City of London, the grocer inside the shop, in sanctuary. ${ }^{86}$

In about the late 1480s, according to William Mathew, Purfote was able to discharge his debt and no longer needed sanctuary ${ }^{87}$ He stayed put, however, in the tenement he had leased from the dean of St. Martin Le Grand. Soon after, he acquired the tenement next door-which had never been sanctuary territory-and knocked down the wall between the tenements to create a shop of twice the size. He opened up a door into the street, on the east side of the house, and closed up the original door that led into the gate. The western part of the house, however, retained its status as sanctuary, the boundary indicated within the house by a large post standing where the wall dividing the two houses had once been. ${ }^{88}$ This anomalous situation continued after Purfote died in 1507 and still held in the mid-1530s, at which time Roger Wright, also a grocer, was the tenant ${ }^{89}$ As Wright himself was not in sanctuary, and he did not have any sanctuary men in his household, the main significance of this sanctuary boundary marker within

84. Depositions of William Mathew, TNA, STAC 2/23/266, mm. 45-50; TNA, STAC 2/20/323, mm. 19-23.

85. In 1474, Robert Purfote enrolled a deed in the City's plea and memoranda rolls (Philip E. Jones, ed., Calendar of Plea and Memoranda Rolls, 1458-1482 [Cambridge: Cambridge University Press, 1961], 170), so presumably his entry into St. Martin's postdated that time. A chancery bill presented 1473-75, however, indicates that around that time Purfote was heavily in debt to William Dalton, merchant of the Calais staple: TNA, C 1/48/144.

86. Deposition of John Marten, TNA, STAC 2/23/266, m. 30.

87. Mathew stated that Purfote was no longer a sanctuary man for the last twenty years of his life, and he died in 1507 or 1508. Deposition of William Mathew, TNA, STAC 2/23/266, mm. 45-56; will of Robert Purfote, grocer, dated 20 Sept. 1507, proved 22 Jan. 1508, TNA, PCC Prob. 11/15, fols. 254v-255r.

88. Depositions of William Mathew, TNA, STAC 2/23/266, mm. 45-50; STAC 2/20/323, mm. 20-21.

89. In January 1537 Wright himself mentions that he was living in the house six or seven years before. Deposition of Roger Wright, TNA, STAC 2/20/323, m. 6. 
the house was in fact on the street outside. The notional line marking the sanctuary boundary on the street proceeded from this sanctuary post in Wright's house up to the channel in the middle of the street outside. From there it ran westward in front of St. Martin's gate, up to the channel in the middle of St. Martin's lane, and then up St. Martin's lane to the end of the Bull's Head tenement, after which the sanctuary bounds ran behind the tenements on the western side of St. Martin's lane along the wall that separated lands belonging to St. Martin Le Grand from the gardens of the Greyfriars.

The final determination of the inquiry about St. Martin's sanctuary rights undertaken in 1536-37 went, not surprisingly in the larger context, against the abbot's case..$^{90}$ In any event, by this point the fate of St. Martin's was caught up in the larger issues of the dissolutions and the Reformation. We need not, however, leap from our hindsight about the inevitability of St. Martin's demise to conclude that the way the sanctuary space was conceptualized and worked in practice in 1536 had by 1538 become irrelevant to understanding English law, justice, and governance.

As Henrietta Moore has noted, "Spatial representations express in their own logic the power relations between different groups; they are therefore active instruments in the production and reproduction of social order." 91 The functioning of the sanctuary of St. Martin Le Grand exemplified and indeed helped to produce some of the more complicated intertwinings of late medieval English law, society, religion, and politics.

Historians have, with a few exceptions, looked with considerable disfavor on the practice of permanent sanctuary in the late Middle Ages and early Tudor period. Major twentieth-century contributors to our understanding of sanctuary, such as Isobel Thornley and Charles Cox, have regarded permanent sanctuaries as repugnant illustrations of the corruption of the late medieval church and the impotence of insufficiently centralized royal government. ${ }^{92}$ Other historians have seen sanctuary as an imperfect response to the arbitrary and inefficient legal systems of an unenlightened era. ${ }^{93}$ Indeed, it is hard sometimes for the modern reader of the 1536-37

90. LMA, Journal 14, fol. 78r, 89v-90r.

91. Moore, Space, Text, and Gender, 88-89.

92. Thornley, "Sanctuary"; Thornley, "Destruction of Sanctuary"; Cox, Sanctuaries; E. W. Ives, "Crime, Sanctuary."

93. E.g., famously Henry Hallam, History of Europe During the Middle Ages (New York: The Colonial Press, 1899), 3:34, http://www.archive.org/details/historyofeuroped03hall (accessed Dec. 2, 2008): "Under a due administration of justice this privilege [permanent sanctuary] would have been simply and constantly mischievous, as we properly consider it 
depositions not to think that the observance of the sanctuary bounds resembled a "child's game," as Paul Hyams has put it, ${ }^{94}$ or to see in it the germ of a Monty Python skit. A boundary post in the middle of someone's house beyond which a sheriff or his sergeant could not cross, or the careful guarding of prisoners being tried before justices at St. Martin's Gate from putting a toe over the boundary line into sanctuary can seem ridiculous. Similarly, once in sanctuary, a hand on a sanctuary boundary was like touching "base" in a game of tag. Let go of the post or the back wall of the tavern, and a sheriff or his servant could haul you off to jail.

Even those scholars who have explicitly eschewed the whiggishness of early twentieth-century understandings of medieval sanctuary still tend to see the practice as having lost its original logic and purpose by the fifteenth century. Karl Shoemaker, Barbara Rosenwein, and Paul Hyams have all argued effectively and persuasively that sanctuary was an integral part of an earlier medieval world where wrongdoing was conceptualized as a breach in relationships between people rather than as an offence against a properly constituted authority, such as the king. The response to such wrongdoing was not punishment as deterrence but instead reconciliation and healing of the social breach-facilitated by the intermediary role of the church and the safe and sacred space of sanctuary. As wrongdoing came to be conceptualized as an offence against authority—as, in England, breaking of the king's peace - and punishment as deterrent, the role of sanctuary as asylum for criminals came to seem antithetical to the desired result of justice (punishment of wrongdoing) rather than supportive of its ends (reconciliation). Thus sanctuary, by the late Middle Ages, Shoemaker says, "had become a genuine threat to emerging concepts of law and order," and its abolition in the sixteenth century in a sense inevitable. ${ }^{95}$

This argument tells part of the story of late medieval sanctuary: the role of sanctuary as asylum for accused criminals was seen by many contemporaries in the late Middle Ages as problematic, and without doubt shifts in ideas about crime, justice, and punishment were an important aspect

\footnotetext{
to be in those countries where it still subsists. But in the rapine and tumult of the middle ages the right of sanctuary might as often be a shield to innocence as an immunity to crime. We can hardly regret, in reflecting on the desolating violence which prevailed, that there should have been some green spots in the wilderness where the feeble and the persecuted could find refuge."

94. Hyams, Rancor, 95.

95. This argument runs through Shoemaker, "Sanctuary Law" (quotation at 25). Similar judgments are made by Paul Hyams, Rancor and Reconciliation in Medieval England (Ithaca: Cornell University Press, 2003), esp. at 95; Barbara H. Rosenwein, Negotiating Space: Power, Restraint, and Privilege of Immunity in Early Medieval Europe (Ithaca: Cornell University Press, 1999), esp. at 206.
} 
of this. As London's mayor and aldermen pointed out (and subsequent historians have repeated), the sacral character of the sanctuary space was an ironic match for the protection it offered to the vilest of sinners, murderers, and thieves. In their statement of claim against St. Martin's in 1536, London's mayor and aldermen assaulted the pretensions of the sanctuary by emphasizing that it had wrongfully defended and left unpunished "all maner of enorme enymyes of god, the chyrche, the kynge, and royalme." 96 The City's argument was similar to that made by fifteenth-century popes and continental canonists, who worried about the refuge and impunity permanent sanctuaries offered to criminal wrongdoers and the scandal sanctuaries created for the church. ${ }^{97}$

But this picture of late medieval English sanctuary as an archaic relic of earlier conceptualizations of law and punishment is incomplete. Its obsolescence by the 1530s is exaggerated: despite long-standing disputes about the nature of the sanctuary at St. Martin Le Grand, sanctuary remained functional as a concept, albeit imperfectly and not without contest, through to at least early 1537 when the latest depositions in this dispute were taken, and in some ways well beyond. The permeability and indeed in some cases the invisibility of the boundaries of the precinct are testament to the continued power of sanctuary into the 1530s. Cromwell may have desired, and in the 1540s partially attained, sanctuary's "utter destruction,"98 but his view of the illegitimacy of the concept of sanctuary was clearly not a common one among those living in and around St. Martin's in the 1530s, ${ }^{99}$ as indicated by the City's inability to find witnesses to testify to its claim for the sanctuary's nonexistence. Nonetheless, scholars such as Isobel Thornley and those who have followed the lines of her argument have represented the mayor and aldermen's arguments as mainstream; in doing so, they have misunderstood the late medieval English context of sanctuary in several ways.

First, this view oversimplifies late medieval English conceptions of the relationship between law, sin, and mercy. The discourse of law, order, and due punishment — and the undue protection of vile criminals in sanctuarywas not the only, or indeed even the majority, point of view in the early Tudor period. Until the 1540s, English kings supported the rights of royally chartered sanctuaries because observing sanctuary not only emphasized limitations on the powers of local civic officials and sheriffs, but because

96. TNA, STAC 2/20/324, "Declarations of the Abbot of Westminster and the Mayor and Aldermen of London regarding the limits of the sanctuary of Saint Martin-le-Grand" (c. 1536), m. 5.

97. Shoemaker, "Sanctuary Law," 224-25, 252-53.

98. Kesselring, Mercy, 52-53; Hertzler, "Abuse," 467-77.

99. Kesselring also notes that Cromwell's views were not mainstream in 1536. "Abjuration," 357. 
it aligned that royal power with the mercy and justice of God. ${ }^{100} \mathrm{~A}$ royal proclamation issued in the name of Henry VI in 1470, in the midst of the most serious struggles of the Wars of the Roses, integrated the reverence due to the "holy places of seintwaries of Westminster and Saint Martin's"and by extension "any minister, servant, inhabitant, or sojornaunt within the said holy places"- with the importance of observing the "sovereign lord's laws and his peace." ${ }^{101}$ As Krista Kesselring has demonstrated, the Tudor kings used their grants of clemency "to enhance their power and legitimize that power as authority." 102 Had not the Reformation and the dissolution of religious houses removed the possibility of the crown's employment of sanctuaries to manifest royal mercy, sanctuaries may well have continued to function in England for some time beyond the 1530s.

These political concepts in turn derived from, and were consonant with, late medieval English Christianity. Many late medieval English people, and arguably most, had fewer difficulties than the antisanctuary rhetoric would suggest in accommodating what might seem to us the contradiction of the church's protection of criminals. ${ }^{103}$ Mercy and charity towards the most despicable of sinners was a central pillar of late medieval Christianity, a reflection of the redemptive powers of Christ: one of the seven works of mercy advocated visiting prisoners, and a common charitable bequest for late medieval Londoners was to donate money to all the prisoners in the City jails. ${ }^{104}$ The Christian duty to succor the poor, the defenseless, and the imprisoned in turn fit well with contemporary suspicions about the sometimes arbitrary nature of political and judicial processes. ${ }^{105}$ If the papacy and continental canonists questioned sanctuary, for the fifteenth-century English, the importance and sacredness of sanctuary space was maintained or even increased. ${ }^{106}$

Secondly, the argument for obsolescence fails to take into account the changes both in practice and in conceptualization that sanctuaries had un-

100. See above n.11.

101. Cora L. Scofield, "Elizabeth Wydevile in the sanctuary at Westminster, 1470," The English Historical Review 24 (1909): 90; Claude Gauvard, "De Grâce especial": Crime, état, et société en France à la fin du moyen âge, 2 vols. continuously paginated (Paris: Publications de la Sorbonne, 1991), esp. 940-41, 951-52, also notes the connection between God's peace and French conceptions of royal mercy.

102. Kesselring, Mercy, 16; see also Gauvard, De Grâce especial, 895-96.

103. Kesselring, Mercy, 17.

104. See Matt. 25:36-44; The Crafte to Lyue Well (Westminster: Wynkyn de Worde, 1505; STC 792), fol. 36r; Phillip Lindley, Miriam Gill, and Alex Moseley, Seven Deadly Sins and Seven Corporal Works of Mercy, 2001, http://www.le.ac.uk/arthistory/seedcorn/contents.html (accessed Dec. 2, 2008); Eamon Duffy, The Stripping of the Altars: Traditional Religion in England 1400-1580 (New Haven: Yale University Press, 1992), 360.

105. Kesselring, "Abjuration," 346, 357; Rosser, "Sanctuary."

106. Kaufman, "Henry VII and Sanctuary." 
dergone by the fifteenth century. Most sanctuary dwellers in the iconic late medieval English sanctuaries of St. Martin's and Westminster were not, in fact, heinous criminals, but were alien craftsmen, debtors, and (especially at particular high points of regime changes) political refugees. Sanctuary's continued vitality in the fifteenth and early sixteenth centuries owed something to its social, political, and economic utility, not only for the debtors, aliens, and refugees themselves, but for the larger society. For some, time in sanctuary was similar to modern bankruptcy protection: time to find the wherewithal to settle debts and reintegrate back into their trade or craft. Robert Purfote, of the house half-in and half-out of sanctuary, is a good example - having fled to sanctuary because of overwhelming debt, he was later able to reestablish himself and died in good standing with the grocer's guild. A number of relatively prominent London merchants had similarly availed themselves of the sanctuary_as Richard Caudray put it in 1440, undoubtedly somewhat hyperbolically, "many of pe Aldermen, Shirefs, Officers and worshipfull comuners of pe seid Citee haue many tymes reioysed and had pe tuicion and immunitee of pe seid seintuarie."107 While Caudray's boast that he could produce the name of three hundred such sanctuary seekers in recent times ${ }^{108}$ can only have been an exaggeration, it is ironic that even Philip Malpas, one of the London sheriffs who had led the assault against the privileges of St. Martin's during Caudray's time as dean, was later to seek sanctuary himself. ${ }^{109}$

The importance of sanctuaries during the civil wars of the fifteenth century, when each change of regime saw a fleeing of the losing party to a convenient nearby sanctuary, ${ }^{110}$ arguably augmented the importance of sanctuary's political and social role. Sanctuary was seen to provide breathing space for

107. WAM, Book 5, fol. 49r.

108. Ibid.

109. TNA, C 49/68/21; CLBK, 241-43; A. H. Thomas and Isobel Thornley, eds., The Great Chronicle of London (London and Aylesbury: George W. Jones, 1938), 195.

110. St. Martin Le Grand offered refuge to Anne Neville, daughter of Warwick the Kingmaker and later wife of Richard, duke of Gloucester (Nicholas Pronay and John Cox, eds., The Crowland Chronicle Continuations: 1459-1486 [London: Alan Sutton Publishing for the Richard III and Yorkist History Trust, 1986], 133); to the Countess of Oxford (Davis, ed., Paston Letters, 1:449); and to John Morton, Bishop of Ely (see above, n.51). Polydore Vergil, Three Books of Polydore Vergil's English History, ed. Henry Ellis (London: John Bowyers Nicols and Son, 1844), http://www.archive.org/details/polydorevergil00camduoft (accessed Dec. 2, 2008), offers various other examples of people fleeing to sanctuary during the fifteenth-century civil wars for political reasons: e.g.: "yt came to passe that right many, fearing the woorst, partly fled into sayntuary, partly submyttyd themselves to the king [Edward IV]" (130); Edward's own wife went into sanctuary at Westminster upon his flight (133); conversely the duke of Exeter went into sanctuary after Barnet, 1471 (147); and Queen Margaret and her son went into sanctuary at Beaulieu (148). During the reign of Richard III, Edward IV's widow Elizabeth Woodville went into sanctuary at Westminster for the second time $(175-78,210)$. 
political opponents of a regime and a chance for a sovereign's sober second thought to prevail over immediate rage: as Polydore Vergil put it, Lancastrian Thomas Dymmok fled to Westminster in 1470, "meaning ther to tary untill the kinges ire should be asswagyd." 111 The political usefulness of immunity did not end with the advent of the Tudors, as even Henry VIII himself used sanctuary as a tool: between 1514 and 1516, Henry VIII paid the expenses of two sanctuary men, to the tune of 100s. a year. ${ }^{112}$

Sanctuaries, especially St. Martin's and Westminster, were also homes to substantial communities of aliens. Although City officials were hostile to their ability to work outside the guild system, others, including the crown, deemed the work of alien craftsmen useful or desirable-Prince Arthur apparently found the shoes Harry Potts made for him worth the protection he allegedly extended to Potts's wallbreaking, for instance. ${ }^{113}$ St. Martin's lane may have been the place to buy fashionable shoes - or to put it in less apparently trivial terms, its freedom from London guild supervision may have allowed more artisanal independence and wider consumer choice than the tightly controlled London guild system. In 1463, when Parliament, at the request of the London cordwainers' guild, legislated a ban on shoemakers of London and environs from making shoes with points longer than two inches, the king explicitly exempted artisans working in the liberty of St. Martin Le Grand from having to comply. ${ }^{114}$

Royal support for the permanent sanctuaries of St. Martin and Westminster, defended by the crown through the fourteenth, fifteenth, and early sixteenth centuries, was clearly motivated at least partly by the London-area sanctuaries' usefulness as a check to the pretensions of the mayor and aldermen of London. Although some legal historians such as J. H. Baker have emphasized the status of St. Martin's and other sanctuaries as territories where "the king's writ did not run" and thus their improper independence from royal power, ${ }^{115}$ the privileged sanctuaries were protected by fifteenthand early sixteenth-century English kings as demonstrations of, rather than

111. Vergil, Three Books of Polydore Vergil's English History, 127.

112. L\&P Hen. VIII, 2/2:1466, http://www.british-history.ac.uk/report.aspx?compid=90980 (accessed Dec. 2, 2008), 2/2:1469, http://www.british-history.ac.uk/report.aspx?compid=90981 (accessed Dec. 2, 2008), 2/2:1471, http://www.british-history.ac.uk/report.aspx?compid=90982 (accessed Dec. 2, 2008). I have not (yet) been able to trace the two men, named John Gamlyn and Thomas Porter, or the reasons for the king's support.

113. See above, n.18. Note also that the 1523 Act Concerning the Taking of Apprentices by Strangers (Statutes of the Realm, 3:208-9) allowed St. Martin's exemptions on the employment of alien joiners and glaziers landowners with lands worth one hundred pounds or more yearly.

114. Given-Wilson, PROME, 5:566.

115. J. H. Baker, An Introduction to English Legal History, 4th ed. (London: Butterworths LexisNexis, 2002), 512-13. Baker finds the practice of sanctuary offensive, the permanent sanctuaries such as St. Martin Le Grand constituting "the greatest evil" of all. Ibid., 512. 
challenges to, royal authority and power. Henry VI, Edward IV, Henry VII, and even the early Henry VIII supported the royally chartered liberties for the same motivations that Barbara Rosenwein has attributed to early medieval kings in granting monasteries immunities: because they affirmed "royal control over public agents and their jurisdiction" (most notably the mayor and aldermen of London in the case of St. Martin Le Grand), and because they announced "control over the configuration of space." 116

Yet it was not only sanctuary's political, economic, and social utility, but perhaps even more importantly its sacrality that underpinned sanctuary's continuing power in the fifteenth and early sixteenth century. The respect accorded to the sanctuary and its dwellers clearly derived to some extent at least from a shared understanding of sanctuary as holy ground. Banal as this observation may seem, it nonetheless bears repeating. This sacrality was clearly linked to the earlier conceptualization of sanctuary and its role in peacemaking and in providing alternatives to violence. ${ }^{117}$ Although the debtors and the alien craftsmen who likely predominated in the late medieval sanctuaries of St. Martin's and Westminster would not have fit easily with early and high medieval conceptualizations of sanctuary as the locus of peacemaking and healing of breaches occasioned by violence, ${ }^{118}$ their presence in sanctuary did fit with late medieval English religiosity. In the late medieval idea of sanctuary, the mercy a just king might show to a murderer, either through pardons or through his support of his royally chartered sanctuaries, was easily connected with the charity properly to be shown to the unfortunate. A treatise written some time between the late fourteenth and mid-fifteenth centuries by a monk of Westminster (and recopied at the end of the fifteenth century) defended the protection of debtors in sanctuary by

116. Rosenwein, Negotiating Space, 7-8, 111 (quotations at 7). Rosenwein herself, in brief discussion of fifteenth- and sixteenth-century English practice of sanctuary, follows Thornley's interpretation that by the Tudor period sanctuary was protected only by a corrupt church and was vigorously opposed by the modernizing Tudors, an argument that has been assailed by most historians of the period more recent than Thornley. Rosenwein, Negotiating Space, 206; Kaufman, "Henry VII and Sanctuary"; Rosser, "Sanctuary and Social Negotiation," esp. 58-60, 74-76; Kesselring, "Abjuration," esp. 354-57. Even Elton would have disagreed with Thornley on this point: as he rather dismissively put it, Henry VIII in the mid-1530s could not "stomach" Cromwell's attempt to destroy sanctuaries, "anxious as always to preserve ecclesiastical claims once they were declared to be derived from him." Reform and Renewal, 137.

117. Helmholz, Ius Commune, 23-30; Shoemaker, "Sanctuary Law," 6-7, 43-44, 23436.

118. Although an anonymous fifteenth-century defender of Westminster sanctuary made the link between debtors and protection against violence by arguing that debtors were in physical danger, as indeed did Thomas More. Helmholz, Ius Commune, 70-72; More, "The Historie of kyng Rycharde the thirde," 47. 
connecting the sacredness of the relics housed in the church with the importance of protecting those trapped by poverty and unable to wield the tools of influence in a corrupt judicial system. ${ }^{119}$ Similarly, sanctuaries' function as asylums for the impotent poor provided early sixteenth-century defenders of permanent sanctuaries with powerful arguments against their dismantling. In the early 1520s, for instance, the poet John Skelton bemoaned the harm that threatened suppressions of sanctuaries would wreak upon vulnerable paupers. ${ }^{120}$ As even the virulent opponent of sanctuary privileges, Sir Thomas More, put it, it was a "deede of pitie" to offer a refuge for those whom losses at sea or other circumstances brought into poverty, keeping them safe from "their cruell creditours." 121 The concept of immunity from criminal prosecution, moreover, could very easily be connected to freedom from prosecution for debt or the trade restrictions imposed by guilds and civic merchant oligarchies. The continued flourishing of the concept of sanctuary in this late period likely owed a good deal to its use by others besides accused felons; especially in the second half of the fifteenth century, the arbitrariness of the fifteenth-century civil wars and the abrupt changes of regime highlighted the sanctuary space as a place apart from worldly tribulations, as a space protected (in the highest rhetoric) by God's mercy and justice. Sanctuary privileges were claimed, perhaps increasingly through this period, most often not by criminals but by those less ambiguously in need of Christian pity, the poor debtor or the alien craftsman, hoping to scratch out a living in defiance of the grasping and protectionist London elite. The common threads were mercy for the unfortunate and redemption even for the vilest sinners.

The sacrality of sanctuary thus continued to function in the early sixteenth century, not as an obsolete relic of earlier conceptions of law, punishment, and the role of the church, but because it dovetailed closely with late medieval and early Tudor conceptions of law, kingship, and Christian charity. Sanctuary worked, imperfectly but functionally, into the 1530s. It could not, however, continue to function in the same way once religious houses were dissolved during the Reformation. The free chapel of St. Martin Le Grand was both institutionally dissolved and physically dismantled in 1542, along with the sanctuary rights associated with the church. Some of the liberties of St. Martin Le Grand, however, lived on long after the dissolution of the religious house in 1542. When St. Martin's was dissolved in 1542, Henry VIII granted that, excepting sanctuary for felons, the liberties that had previously been accorded to the church-its separate status from the City as far

119. Rosser, "Sanctuary and Social Negotiation," 71; Kaufman, The "Polytyque Churche," 148-49; Helmholz, Ius Commune, 70-72.

120. Rosser, Medieval Westminster, 221.

121. More, "The Historie of kyng Rycharde the thirde," 47. 
as alien craftsmen and debtors were concerned-were to continue. He even delineated precisely where those liberties should be observed: "within the site of the college of St. Martin and Dean's Court, Powche Makers' Court, St. Martin's lane, Angell alley, Bell alley, St. John's alley, Cocke alley, Cristofer alley, Fowerdoves alley, and Bland's alley." ${ }^{22}$ In other words, he granted that all the territories that had been claimed by the most expansionist versions of the sanctuary were to continue to be acknowledged as a liberty, vindicating to some extent the abbot's case in 1536-37. But—crucially - the liberty now had its basis only in royal grant, not in any holiness inhering in the now churchless site. It is hard to know to what extent and for how long Londoners might have nonetheless continued to associate the territory's status as a liberty with its former sacrality. In 1558, City of London viewers recorded that an area in the precinct was "privileged and sanctuary ground," 23 but this was, significantly, during Mary's reign, when arguments were raised (then dropped, even before Mary's death) about reinstituting sanctuary privileges at Westminster. ${ }^{124}$ John Stow, writing his great Survey of London around 1600, tells us that after the college church was pulled down, "a large Wine tauerne was builded," and many houses were built and leased to aliens. In practicing their trades in the precinct, those aliens, he said, acted as the merchants in the temple mentioned in the twenty-first chapter of Matthew, in contrast to the canons of old who had served God day and night. ${ }^{125}$ Thus the old precinct—on both sides of St. Martin's lanecontinued to bear many of the immunities that had been associated with the church for several centuries, retaining its status as a liberty within the City and thus as a haven for alien craftsmen and debtors. And some of the more traditional thinkers in late Elizabethan England-like John Stow-thought it a shame that they did so without reference to the old Christian bases of the immunity claims.

122. L\&P Hen. VIII, 17:396, no. 714/5, http://www.british-history.ac.uk/report.aspx ?compid=76667 (accessed Dec. 2, 2008).

123. Janet Senderowitz Loengard, ed., London Viewers and their Certificates, 1508-1558: Certificates of the Sworn Viewers of the City of London (London Record Society, 1989), no. 397, $<$ http://www.british-history.ac.uk/report.aspx?compid=36062> (accessed Dec. 2, 2008).

124. See Arthur Penrhyn Stanley, Historical Memorials of Westminster Abbey, 2nd ed. (London: John Murray, 1868), 610-16.

125. John Stow, A suruay of London. Conteyning the originall, antiquity, increase, moderne estate, and description of that city, written in the yeare 1598. by Iohn Stow citizen of London. Since by the same author increased, with diuers rare notes of antiquity, and published in the yeare, 1603 (London: John Windet, 1603; STC 23343), 311. This passage does not appear in the 1598 version of his Survey (A Suruay of London [London: John Windet, 1598; STC 23341], 246), but was part of the "increase" of the 1603 edition. 